\title{
Biodeinking Kertas Koran Bekas menggunakan Ekstrak Kasar Lakase dari Marasmiellus palmivorus
}

\author{
Sitatun Zunaidah ${ }^{1}$, Rendana Saputra ${ }^{2}$, Sri Harjati Suhardi ${ }^{1,2}$, Hendro Risdianto ${ }^{3}$ \\ ${ }^{1}$ Sekolah Ilmu dan Teknologi Hayati, Institut Teknologi Bandung, Jl. Ganesha 10, Bandung, Indonesia \\ ${ }^{2}$ Pusat Penelitian Biosains dan Bioteknologi, Institut Teknologi Bandung, Jl. Ganesha 10, Bandung, Indonesia \\ ${ }^{3}$ Balai Besar Pulp dan Kertas, Jl. Raya Dayeuhkolot 132, Bandung, Indonesia
}

Diterima : 5 Januari 2021, Revisi akhir: 24 Juni 2021, Disetujui terbit : 29 Juni 2021

\section{Biodeinking of Old Newspaper using Crude Laccase from Marasmiellus palmivorus}

\begin{abstract}
Enzymatic deinking is receiving growing attention due to the negative environmental impact caused by chemical deinking. Old newspaper (ONP) is one of the materials that can be used in paper recycling. The use of the crude laccase from Marasmiellus palmivorus in biodeinking is due to its capability to remove the ink. The objective of this research was to determine the potential use of laccase in enzymatic deinking to increase the brightness value and reduce ERIC (Effective Residual Ink Concentration) value on old newspapers. Laccase was produced from M. palmivorus by using cultivation in a static Solid State Fermentation (SSF) reactor with lignocellulosic as substrate. The methodology involves the production of crude laccase extract, laccase optimization using variations of dosage, temperatures, and times. The highest laccase activity is 1,142.86 U/L (16 U/mg). Optimization of laccase crude extract enzyme in biodeinking can increase brightness values by $15.22 \%$ (54.27\%ISO) to $25.03 \%(58.89$ $\%$ ISO) compared to controls (47.09\% ISO) and reduce ERIC values by $46.12 \%$ (452.1 ppm) to $68.26 \%$ (266.4 ppm) compared to control (839.2 ppm).
\end{abstract}

Keywords: biodeinking, Marasmiellus palmivorus, laccase, old newspaper

\begin{abstract}
Abstrak
Deinking enzimatis semakin mendapat perhatian karena dampak negatif terhadap lingkungan yang disebabkan oleh deinking secara kimia. Kertas koran bekas merupakan salah satu bahan yang dapat didaur ulang. Pemanfaatan ekstrak kasar lakase dari Marasmiellus palmivorus digunakan dalam biodeinking karena memiliki kemampuan untuk menyisihkan tinta. Penelitian ini bertujuan untuk mengetahui potensi ekstrak kasar lakase untuk meningkatkan nilai brightness (derajat cerah) dan menurunkan nilai Effective Residual Ink Concentration (ERIC) dalam proses biodeinking kertas koran bekas. Produksi ekstrak kasar lakase dilakukan dalam reaktor statis Solid State Fermentation (SSF) dengan substrat material lignoselulosik. Produksi ekstrak kasar lakase menghasilkan aktivitas tertinggi 1.142,86 U/L (8,33 U/mg). Perlakuan biodeinking dengan enzim ekstrak kasar lakase dapat meningkatkan nilai derajat cerah $15,22 \%(54,27 \%$ ISO) sampai $25,03 \%(58,89 \%$ ISO) dibandingkan dengan kontrol (47,10\%ISO) dan menurunkan nilai ERIC 46,12\% (452,1 ppm) sampai 68,26\% (266,4 ppm) dibandingkan dengan kontrol (839,2 ppm).
\end{abstract}

Kata kunci: biodeinking, Marasmiellus palmivorus, lakase, kertas koran bekas 


\section{Pendahuluan}

Kebutuhan bahan baku kertas terutama yang berasal dari kertas bekas (recovered paper) dunia meningkat dari 50,2 juta ton di tahun 2008 menjadi 58,8 juta ton di tahun 2017 (ISRI, 2019). Pemulihan serat dari recovered paper untuk membuat kertas daur ulang bermutu tinggi dapat berasal dari old magazine (OMG), mix office waste (MOW), dan old newspaper (ONP) (Akbarpour, Ghaffar and Ghasemian, 2017).

Salah satu masalah dalam persiapan bahan baku sekunder adalah pemisahan tinta dari serat selulosa dan penghilangannya. Proses ini dikenal sebagai deinking. Tujuan utama dari proses deinking adalah untuk menghasilkan kertas berkualitas baik dengan sifat optik dan mekanik yang baik (Akbarpour, Ghaffar and Ghasemian, 2017).

Deinking dapat menggunakan bahan kimia atau enzim. Deinking menggunakan bahan kimiawi menghasilkan limbah buangan yang tidak ramah lingkungan dan pengelolaannya membutuhkan biaya yang tidak sedikit. Untuk itu teknologi deinking berbasis enzim dikembangkan sebagai solusi yang ramah lingkungan (Saxena and Singh Chauhan, 2017).

Enzim yang digunakan dalam daur ulang kertas harus memiliki kemampuan yang cukup baik dalam meningkatkan dan mempertahankan kualitas kertas sekunder yang dihasilkan. Lakase merupakan salah satu enzim yang dapat digunakan pada proses deinking (Saxena and Singh Chauhan, 2017). Ekstrak kasar lakase dapat dihasilkan dari kelompok jamur pelapuk putih Marasmiellus palmivorus. Produksi dan aktivitasnya sudah pernah diteliti (Permana, 2016); demikian pula aplikasinya pada proses pemutihan pulp (Risdianto et al., 2012), dan enhanced oil recovery (Rumintang, 2016).

Lakase merupakan hasil metabolisme sekunder dari jamur pelapuk putih pada kondisi tertentu seperti nitrogen dan karbon yang terbatas (Viswanath et al., 2014). Pada proses biodeinking, lakase berperan mengoksidasi gugus hidroksil fenolik pada lignin pulp menjadi fenoksi radikal bersamaan dengan reduksi oksigen menjadi air. Adanya reaksi ini menyebabkan lignin terdepolimerisasi dan membentuk gugus hidrofil fungsional sehingga dapat dihilangkan saat proses pencucian. Saat lignin dihilangkan, ikatan antara serat dan partikel tinta menjadi longgar. Selanjutnya dengan bantuan gaya geser dari peralatan deinking, partikel tinta terlepas dari serat pulp (Singh et al., 2017).

Penelitian terkait biodeinking dengan menggunakan enzim telah dilaporkan dan terbukti dapat meningkatkan kualitas optis kertas dari serat sekunder (Virk et al., 2013; Gupta et al., 2015; Hong et al., 2017; Shankar et al., 2018). Oleh karena itu, dalam penelitian ini dilakukan proses biodeinking kertas koran bekas dengan menggunakan ekstrak kasar lakase dari jamur M. palmivorus dengan optimasi perlakuan dosis enzim, waktu biodeinking, dan suhu perlakuan. Metode ini diharapkan dapat menjadi acuan untuk meningkatkan kualitas derajat cerah kertas dari serat sekunder dan menurunkan nilai Effective Residual Ink Concentration (ERIC).

\section{Bahan dan Metode}

\section{Mikroorganisme}

Isolat jamur $M$. palmivorus dalam media Potato Dextrose Agar (PDA) diperoleh dari Laboratorium Mikologi, Pusat Penelitian Biosains dan Bioteknologi, Institut Teknologi Bandung.

\section{Produksi Ekstrak Kasar Lakase}

Isolat dibuat menjadi 2 subkultur yaitu kultur stok dan kultur kerja. Subkultur dilakukan ke dalam media PDA yang telah disterilkan dalam autoklaf suhu $121^{\circ} \mathrm{C}$ tekanan $1,5 \mathrm{~atm}$ selama 15 menit. Media steril yang masih hangat dituang ke dalam cawan Petri. Media kemudian didinginkan, setelah memadat isolat diinokulasikan ke dalam media dengan ukuran inokulum $\pm 1 \mathrm{~cm}$, kemudian ditutup dengan plastic wrap. Subkultur diinkubasi pada suhu ruang selama \pm 5 hari sampai pertumbuhan jamur memenuhi cawan petri.

Perbanyakan jamur dilakukan dari media PDA ke media baglog (tahap preconditioning). Komposisi baglog adalah serbuk kayu, kapur $2,5 \%$ dari serbuk kayu, NPK 1\% dari serbuk kayu, dan dedak 5\% dari serbuk kayu (Permana, 2016). Sebelum diinokulasi dengan jamur, media bag log dalam plastik tahan panas disterilisasi dalam autoklaf dengan suhu $121 \mathrm{oC}$ tekanan 1,5 atm selama 60 menit. Media baglog selanjutnya didinginkan selama \pm 6 jam. Selanjutnya kultur dalam baglog diinkubasi dalam suhu ruang selama \pm 14 hari sampai pertumbuhan jamur memenuhi baglog. 
Kultur dalam media preconditioning kemudian dipindahkan ke dalam media baru dengan metode Solid State Fermentation (SSF) menggunakan baki. Proses SSF dilakukan selama 14 hari pada suhu ruang. Ekstrak kasar lakase diproduksi dengan mengekstrak kultur jamur dari media SSF menggunakan buffer natrium fosfat pH 6, konsentrasi $200 \mathrm{mM}$. Kultur dalam baki diambil sebanyak $1 \mathrm{~kg}$ dan dibagi ke dalam 4 Erlenmeyer (masing-masing $250 \mathrm{~g}$ ), selanjutnya ditambah buffer natrium fosfat sebanyak $500 \mathrm{~mL}$ (perbandingan kultur : buffer $=1: 2$ ), selanjutnya di-shaker dengan kecepatan $150 \mathrm{rpm}$ selama 2 jam, selanjutnya disaring dengan kertas saring dan disentrifugasi pada kecepatan $5000 \mathrm{rpm}$ selama 10 menit untuk mengendapkan sisa medium SSF yang masih tertinggal. Supernatan digunakan untuk menentukan aktivitas lakase.

Aktivitas ekstrak kasar lakase diuji dengan menggunakan 2,2'-azino-bis (3-ethylbenzhiazoline-6-sulhonic acid) (ABTS) sebagai substrat uji. Oksidasi ABTS diukur berdasarkan peningkatan absorbansinya pada panjang gelombang $420 \mathrm{~nm}$ dengan spektrofotometer UV-Vis (Genesys 10S). Perhitungan aktivitas ekstrak kasar lakase sesuai dengan mengikuti Persamaan 1 (Baltierra-Trejo, Márquez-Benavides and Sánchez-Yáñez, 2015)

$$
U L^{-1}=\frac{(\Delta A)\left(V_{t}\right)\left(D_{f}\right)\left(10^{6}\right)}{(t)(\varepsilon)(d)\left(V_{s}\right)}
$$

Keterangan :

$U \quad$ : aktivitas enzim $\left(\mu \mathrm{mol} \mathrm{min}^{-1}\right)$.

$\triangle A \quad$ : absorbansi akhir - absorbansi awal.

$V_{t} \quad$ : volume total reaksi (mL).

$t \quad$ : waktu reaksi (menit).

$\varepsilon \quad$ : absorptivitas molar $\left(\mathrm{M}^{-1} \mathrm{~cm}^{-1}\right.$ atau $\mathrm{L} \mathrm{mol}^{-1} \mathrm{~cm}^{-1}$ ).

$d \quad$ : panjang optic/kuvet $(1 \mathrm{~cm})$.

$V_{s} \quad$ : volume sampel $(\mathrm{mL})$.

$D_{f} \quad$ : faktor pengenceran

\section{Biodeinking Kertas Koran Bekas dengan Ekstrak Kasar Lakase}

Kortas koran bekas dari salah satu industri kertas koran di Jawa Timur digunakan untuk proses biodeinking. Tahapan biodeinking meliputi tahap enzimatis dan tahap pencucian dengan flotasi. Konsistensi substrat pulp kertas koran bekas yang digunakan adalah $1 \%$ dari volume total reaksi. Optimasi perlakuan enzim dilakukan dengan memberikan variasi perlakuan parameter dosis enzim (15; 32,5; dan $50 \mathrm{U} / \mathrm{L})$, waktu (15 dan 45 menit), dan suhu (30, 35, dan $\left.40^{\circ} \mathrm{C}\right)$. Rancangan percobaan disajikan dalam Tabel 1 dengan tiap tempuhan dilakukan secara duplo.

Tabel 1. Rancangan percobaan

\begin{tabular}{cccc}
\hline Tempuhan & $\begin{array}{c}\text { Dosis } \\
(\mathrm{U} / \mathrm{L})\end{array}$ & $\begin{array}{c}\text { Waktu } \\
(\text { menit })\end{array}$ & $\begin{array}{c}\text { Suhu } \\
\left({ }^{\circ} \mathrm{C}\right)\end{array}$ \\
\hline 1 & 15 & 15 & 30 \\
2 & 15 & 15 & 35 \\
3 & 15 & 15 & 40 \\
4 & 15 & 45 & 30 \\
5 & 15 & 45 & 35 \\
6 & 15 & 45 & 40 \\
7 & 33 & 15 & 30 \\
8 & 33 & 15 & 35 \\
9 & 33 & 15 & 40 \\
10 & 33 & 45 & 30 \\
11 & 33 & 45 & 35 \\
12 & 33 & 45 & 40 \\
13 & 50 & 15 & 30 \\
14 & 50 & 15 & 35 \\
15 & 50 & 15 & 40 \\
16 & 50 & 45 & 30 \\
17 & 50 & 45 & 35 \\
18 & 50 & 45 & 40 \\
\hline
\end{tabular}

\section{Flotasi}

Bubur kertas dari perlakuan enzim dimasukkan dalam reaktor flotasi dengan volume air $2 \mathrm{~L}$ (Vicente and Teixeira (1995). Tween 80 (0,05\% w/v) ditambahkan ke dalam sistem sebagai agen pembuih. Perlakuan dijalankan selama 12 menit. Buih yang terbentuk dan terkumpul di permukaan reaktor dibuang.

\section{Pembuatan dan Pengujian Lembaran}

Setelah proses flotasi, buburan kertas diambil untuk dibuat lembaran sesuai dengan SNI ISO 3688:2014 - Pulp - Cara pembuatan lembaran pulp laboratorium untuk pengukuran faktor pantul baur biru (derajat cerah ISO). Proses deinking dan 
pembuatan lembaran juga dilakukan untuk variasi tanpa menggunakan enzim dan disebut sebagai kontrol. Lembaran kertas yang telah kering diukur nilai derajat cerah sesuai dengan SNI ISO 2470-1 - Kertas, karton, dan pulp - Cara uji faktor pantulan baur biru - Bagian 1: Kondisi siang hari di dalam ruangan (derajat cerah ISO) dan ERIC sesuai dengan TAPPI T 567 - Determination of effective residual ink concentration (ERIC) by infrared reflectance measurement.

\section{Hasil dan Pembahasan}

\section{Produksi Ekstrak Kasar Lakase}

Rata-rata berat media SSF ditambah dengan inokulum M. palmivorus mengalami penurunan hingga 14 hari inkubasi (Tabel 2). Hal ini menunjukkan bahwa jamur tumbuh dengan memanfaatkan media sebagai sumber energi dan dikonversi menjadi biomassa, metabolit, dan gas hasil respirasi tampak pembentukan uap air di dalam media. Lakase dapat diekstraksi secara optimal dengan menggunakan buffer $\mathrm{pH}$ 4,8-6,0 (Vikineswary, 2006).

Tabel 2. Berat media dan jamur pada proses SSF sebelum dan sesudah masa inkubasi 14 hari.

\begin{tabular}{cccc}
\hline Baki & $\begin{array}{c}\text { Media } \\
\text { SSF awal } \\
(\mathrm{g})\end{array}$ & $\begin{array}{c}\text { Media SSF dan } \\
\text { inokulum }(\mathrm{g})\end{array}$ & $\begin{array}{c}\text { Berat akhir } \\
(\mathrm{g})\end{array}$ \\
\hline 1 & 1000 & 1387 & 1325 \\
2 & 1000 & 1370 & 1256 \\
\hline
\end{tabular}

Aktivitas spesifik lakase paling tinggi yang diperoleh adalah $8,33 \mathrm{U} / \mathrm{mg}(1142,86 \mathrm{U} / \mathrm{L})$ dicapai pada hari ke-14 inkubasi. Hasil ini lebih tinggi dibandingkan penelitian sebelumnya yang dilakukan oleh Risdianto et al., (2012) dengan aktivitas sebesar 1116,11 pada hari ke-10. Aktivitas lakase dapat ditingkatkan dengan meningkatkan distribusi oksigen dalam bioreaktor (Perdani et al., 2020). Selain itu, aktivitas lakase juga dipengaruhi oleh suhu dan waktu penyimpanan enzim (Risdianto and Sugesty, 2020). Ukuran partikel (substrat) yang kecil dapat meningkatkan luas kontak antara jamur dan substrat namun mengganggu pertumbuhan dari jamur karena dapat menyebabkan akumulasi substrat sehingga proses distribusi oksigen ke dalam media terganggu (Hanung et al., 2013). Terhambatnya pertumbuhan jamur dapat menurunkan produksi lakase yang dihasilkan (Sayyed et al., 2020).

\section{Biodeinking Kertas Koran Bekas dengan Ekstrak Kasar Lakase}

Biodeinking dengan ekstrak kasar lakase dilakukan pada variasi dosis, suhu dan waktudengan hasil disajikan pada Tabel 3. Signifikansi dari tiap variasi tersebut diperiksa dengan analisis ANOVA seperti disajikan dalam Tabel 4 dan Tabel 5.

Tabel 4 menunjukkan bahwa secara keseluruhan pemodelan untuk respon derajat cerah memberikan pengaruh yang signifikan dibandingkan dengan kontrol dengan nilai $\mathrm{P}$ $($ sig. $)<0,05$. Variasi dosis yang diberikan dalam penelitian ini tidak memberikan pengaruh yang signifikan terhadap respon derajat cerah jika dibandingkan dengan kontrol dengan nilai $\mathrm{p}$ (sig.) $>0,05)$. Sedangkan variasi waktu dan suhu memberikan pengaruh nyata terhadap respon derajat cerah dengan nilai $\mathrm{p}$ (sig.) $<0,05$. Interaksi dari faktor-ketiga variasi memberikan pengaruh signifikan terhadap derajat cerah (sig. $<0,05$ ), tetapi interaksi (waktu*suhu) tidak berpengaruh signifikan.

Pemodelan ini memberikan pengaruh yang signifikan terhadap respon nilai ERIC dibandingkan dengan kontrol dengan nilai p (sig.) < 0,05 (Tabel 5). Variasi dosis dan suhu memberikan pengaruh yang signifikan (sig. < 0,05), sedangkan variasi waktu tidak berpengaruh signifikan (sig. $>0,05)$. Interaksi ketiga variasi tersebut memiliki pengaruh yang signifikan terhadap nilai ERIC.

Nilai derajat cerah bervariasi dengan rata-rata nilai terendah sebesar 54,27 \%ISO dan rata-rata nilai tertinggi sebesar 58,89 \%ISO. Persentase peningkatan derajat cerah kertas sekunder jika dibandingkan dengan rata-rata kontrol secara umum mencapai $15,22 \%$ (54,27 \% ISO) sampai $25,03 \%(58,89 \%$ ISO). Data ini menunjukkan adanya perbedaan nilai derajat cerah yang cukup signifikan antara sampel kertas yang diberi perlakuan enzim dibandingkan tanpa perlakuan enzim. Berdasarkan nilai derajat cerah yang diperoleh setelah perlakuan enzim membuktikan bahwa perlakuan suhu, waktu, dan dosis enzim dapat meningkatkan kualitas optis dari kertas koran bekas (Gambar 1). 
Tabel 3. Derajat cerah dan nilai ERIC proses biodeinking pada berbagai variasi percobaan

\begin{tabular}{cccccc}
\hline Tempuhan & $\begin{array}{c}\text { Dosis } \\
(\mathrm{U} / \mathrm{L})\end{array}$ & $\begin{array}{c}\text { Waktu } \\
(\text { menit })\end{array}$ & $\begin{array}{c}\text { Suhu } \\
\left({ }^{\circ} \mathrm{C}\right)\end{array}$ & $\begin{array}{c}\text { Derajat cerah } \\
(\% \mathrm{ISO})\end{array}$ & $\begin{array}{c}\text { Nilai ERIC } \\
(\mathrm{ppm})\end{array}$ \\
\hline 1 & 15,0 & 15 & 30 & 54,27 & 452,1 \\
2 & 15,0 & 15 & 35 & 55,62 & 385,8 \\
3 & 15,0 & 15 & 40 & 57,57 & 380,4 \\
4 & 15,0 & 45 & 30 & 57,61 & 359,5 \\
5 & 15,0 & 45 & 35 & 56,04 & 367,7 \\
6 & 15,0 & 45 & 40 & 58,26 & 287,6 \\
7 & 32,5 & 15 & 30 & 57,56 & 266,4 \\
8 & 32,5 & 15 & 35 & 57,02 & 273,7 \\
9 & 32,5 & 15 & 40 & 55,69 & 409,8 \\
10 & 32,5 & 45 & 30 & 56,10 & 374,0 \\
11 & 32,5 & 45 & 35 & 56,98 & 345,3 \\
12 & 32,5 & 45 & 40 & 55,56 & 392,2 \\
13 & 50,0 & 15 & 30 & 54,63 & 376,1 \\
14 & 50,0 & 15 & 35 & 56,30 & 323,0 \\
15 & 50,0 & 15 & 40 & 55,71 & 353,2 \\
16 & 50,0 & 45 & 30 & 54,75 & 345,1 \\
17 & 50,0 & 45 & 35 & 56,07 & 306,3 \\
18 & 50,0 & 45 & 40 & 58,89 & 330,7 \\
\hline
\end{tabular}

Tabel 4 Analisis varian (ANOVA) terhadap respon derajat cerah

\begin{tabular}{|c|c|c|c|c|c|}
\hline Source & $\begin{array}{c}\text { Sum of } \\
\text { Squares }\end{array}$ & df & $\begin{array}{l}\text { Mean } \\
\text { Square }\end{array}$ & $\mathrm{F}$ & Sig. \\
\hline Corrected Model & $218,432^{\mathrm{a}}$ & 18 & 12,135 & 24,410 & 000 \\
\hline Intercept & 81400,822 & 1 & & & 000 \\
\hline Dosis & 1,518 & 2 &, 759 & 1,527 & ,243 \\
\hline Waktu & 3,591 & 1 & 3,591 & 7,223 &, 015 \\
\hline Suhu & 7,640 & 2 & 3,820 & 7,684 & ,004 \\
\hline Dosis * Waktu & 6,607 & 2 & 3,303 & 6,645 & ,006 \\
\hline Dosis * Suhu & 21,756 & 4 & 5,439 & 10,941 & ,000 \\
\hline Waktu * Suhu & 2,406 & 2 & 1,203 & 2,420 & ,116 \\
\hline $\begin{array}{l}\text { Dosis * Waktu* } \\
\text { Suhu }\end{array}$ & 11,674 & 4 & 2,918 & 5,870 & ,003 \\
\hline Error & 9,446 & 19 & ,497 & & \\
\hline Total & 118921,470 & 38 & & & \\
\hline Corrected Total & 227,877 & 37 & & & \\
\hline
\end{tabular}


Tabel 5. Analisis varian (ANOVA) terhadap respon nilai ERIC

\begin{tabular}{|c|c|c|c|c|c|}
\hline Source & $\begin{array}{l}\text { Sum of } \\
\text { Squares }\end{array}$ & $\mathrm{df}$ & Mean Square & $F$ & Sig. \\
\hline Corrected Model & $529483,425^{\mathrm{a}}$ & 18 & 29415,746 & 48,573 & ,000 \\
\hline Intercept & 5415594,312 & 1 & 5415594,312 & 8942,562 &, 000 \\
\hline Dosis & 7826,713 & 2 & 3913,356 & 6,462 & ,007 \\
\hline Waktu & 1362,102 & 1 & 1362,102 & 2,249 &, 150 \\
\hline Suhu & 5980,354 & 2 & 2990,177 & 4,938 & ,019 \\
\hline Dosis * Waktu & 22715,155 & 2 & 11357,577 & 18,754 &, 000 \\
\hline Dosis * Suhu & 28895,792 & 4 & 7223,948 & 11,929 &, 000 \\
\hline Waktu * Suhu & 5101,406 & 2 & 2550,703 & 4,212 &, 031 \\
\hline $\begin{array}{l}\text { Dosis * Waktu* } \\
\text { Suhu }\end{array}$ & 7041,022 & 4 & 1760,256 & 2,907 &, 049 \\
\hline Error & 11506,355 & 19 & 605,598 & & \\
\hline Total & 5946824,065 & 38 & & & \\
\hline Corrected Total & 540989,780 & 37 & & & \\
\hline
\end{tabular}

${ }^{\mathrm{a}} \mathrm{R}$ Squared $=0,979$ (Adjusted $\mathrm{R}$ Squared $=0,959$ )

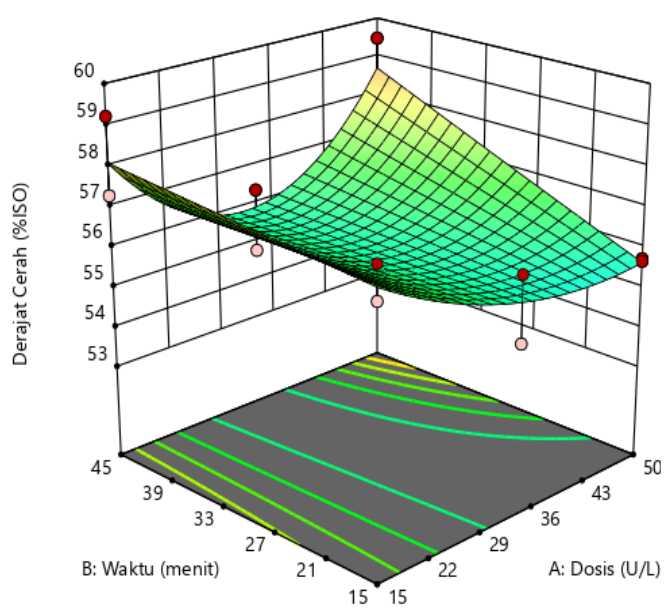

a. Pengaruh waktu dan dosis

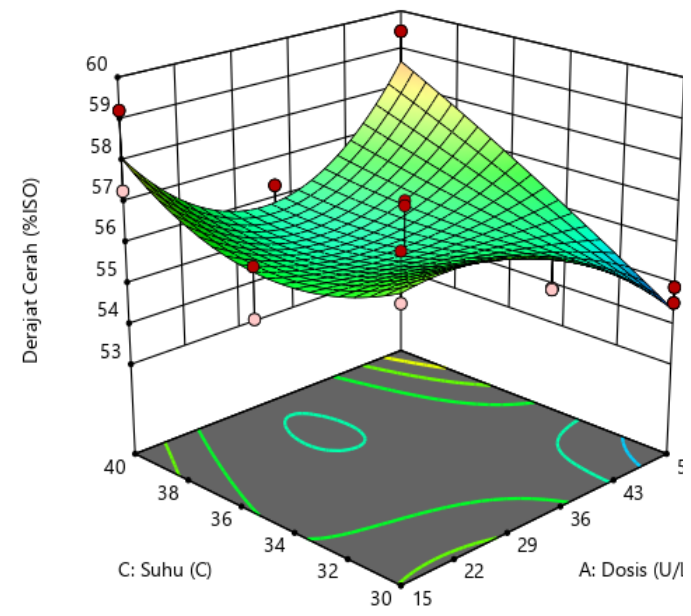

b. Pengaruh suhu dan dosis

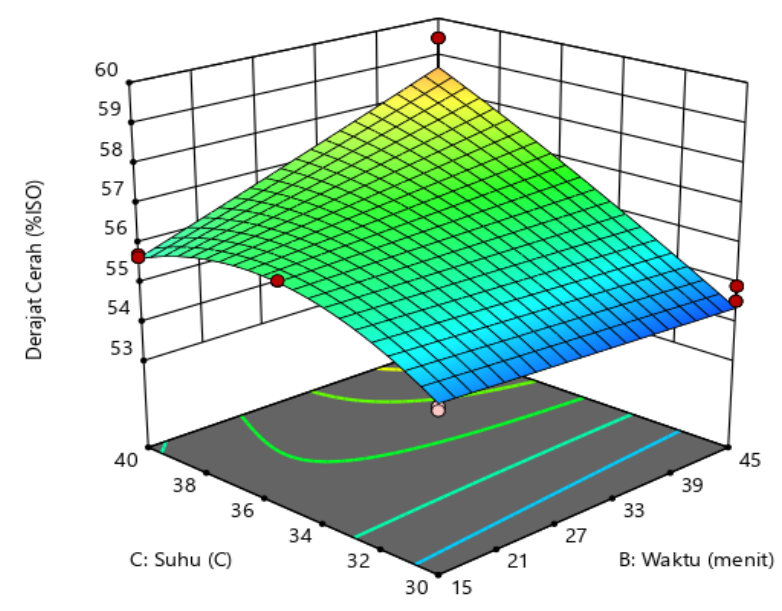

c. Pengaruh suhu dan waktu

Gambar 1. Pengaruh perlakuan enzim pada proses biodeinking kertas koran bekas terhadap derajat cerah 
Perubahan derajat cerah pada sampel dengan perlakuan enzim dan tanpa perlakuan enzim (kontrol) disajikan pada Gambar 2. Nilai derajat cerah kontrol adalah 47,10 \%ISO dan nilai derajat cerah yang diberi perlakuan enzim adalah 58,89 \%ISO. Derajat cerah ini adalah nilai tertinggi yang diperoleh dengan perlakuan dosis enzim $50 \mathrm{U} / \mathrm{L}$, waktu 45 menit, dan suhu $40^{\circ} \mathrm{C}$.

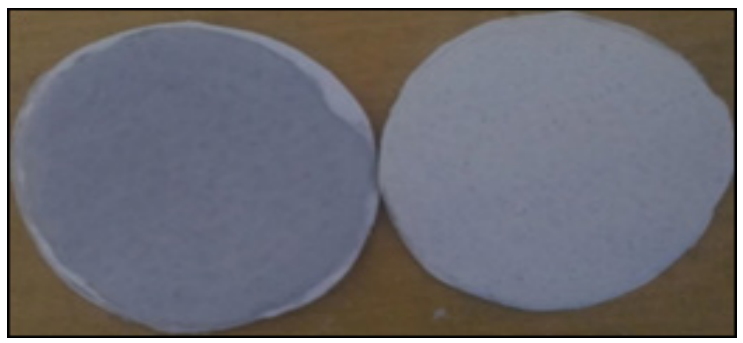

Gambar 2. Pulp yang telah dibentuk menjadi pad kertas. Kontrol (kiri), hasil dengan perlakuan lakase (kanan)

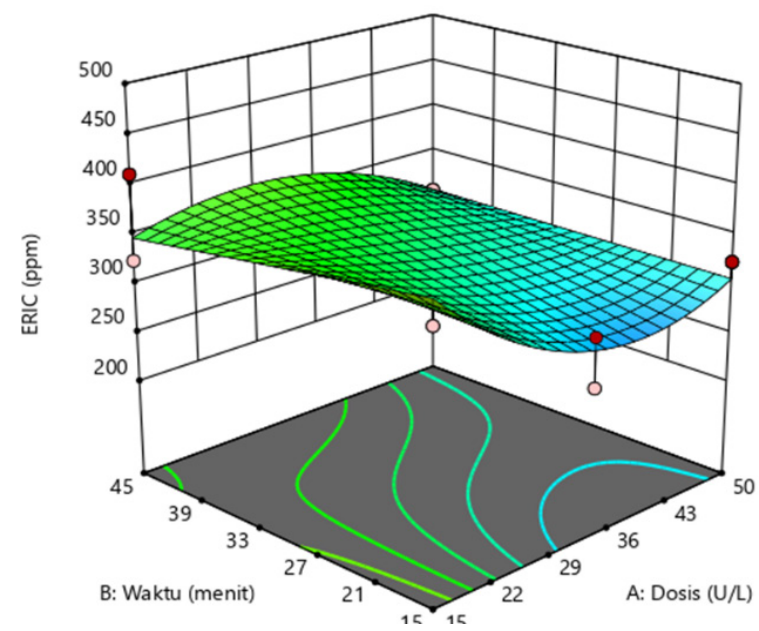

a. Pengaruh waktu dan dosis
Nilai ERIC ditentukan untuk menganalisis efektivitas proses biodeinking berdasarkan variasi suhu, waktu, dan dosis enzim. Nilai ERIC dievaluasi berdasarkan penurunan jumlah residu tinta pada lembaran. Nilai ERIC untuk kontrol adalah 839,2 ppm. Semakin besar persentase penurunan residu tinta, maka semakin efektif proses biodeinking yang dilakukan (Gambar 3). Rata-rata penurunan ERIC terendah sebesar 46,1\% (452,1 ppm) sedangkan rata-rata penurunan ERIC tertinggi mencapai 68,3\% (266,4 ppm). Hasil yang diperoleh (Gambar 3), menunjukkan adanya perbedaan nilai ERIC yang signifikan antara sampel kertas yang diberi perlakuan enzim dibandingkan tanpa perlakuan enzim. Rata-rata residu tinta (ERIC) pada kertas sekunder paling kecil dihasilkan pada proses biodeinking dengan dosis enzim 32,5 U/L, waktu perlakuan 15 menit, dan suhu $30^{\circ} \mathrm{C}$.

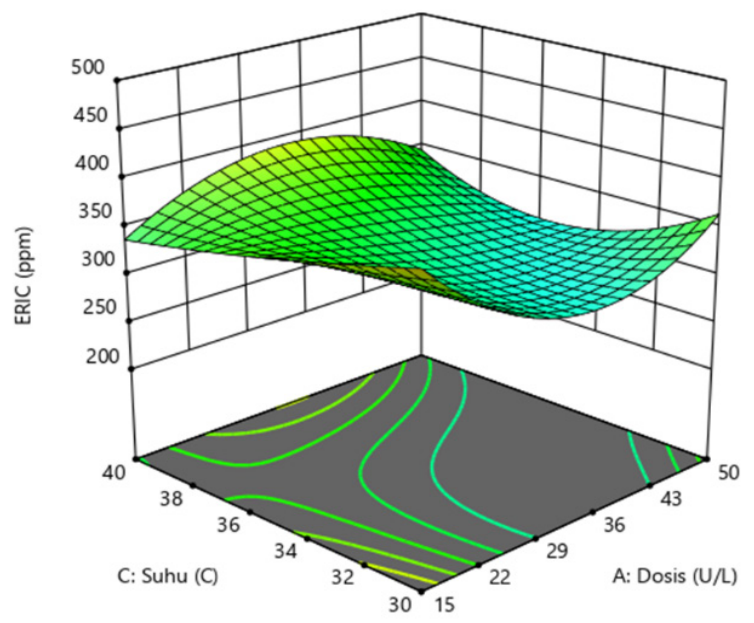

b. Pengaruh suhu dan dosis

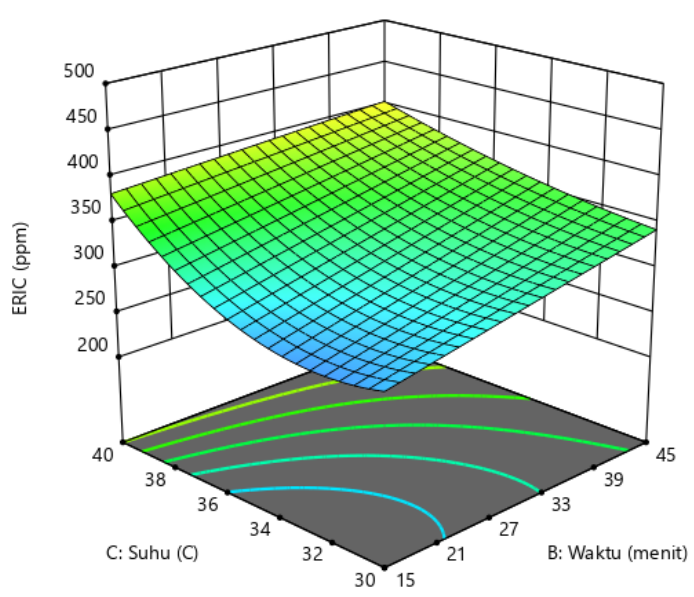

c. Pengaruh suhu dan waktu

Gambar 3. Pengaruh pemberian enzim pada proses biodeinking kertas koran bekas terhadap nilai ERIC 
Tabel 6. Perbandingan dengan penelitian lain untuk biodeinking kertas koran bekas

\begin{tabular}{llccl}
\hline No. & \multicolumn{1}{c}{ Enzim } & $\begin{array}{c}\text { Peningkatan } \\
\text { derajat cerah (\%) }\end{array}$ & $\begin{array}{c}\text { Penurunan nilai } \\
\text { ERIC }(\%)\end{array}$ & \multicolumn{1}{c}{ Pustaka } \\
\hline 1 & Lakase & 21,6 & - & Virk et al., (2013) \\
2 & Xilanase dan lakase & 28,8 & 73,9 & Virk et al., (2013) \\
3 & Selulase dan lakase & - & 49,0 & Xu et al., (2009) \\
4 & Hemiselulase dan lakase & 5,7 & 52,8 & Xu et al., (2009) \\
5 & Cutinase & $4,38-5,13$ & - & Hong et (al., 2017) \\
6 & Lipase & 17,98 & 43,4 & Leduc, Lanteigne-Roch and \\
& & & & Daneault, (2011) \\
7 & Hemiselulase dan lakase & 3,9 & 36,48 & Xu et al., (2011) \\
8 & Lakase & 24,78 & 67,89 & Penelitian ini \\
\hline
\end{tabular}

Enzim berfungsi sebagai biokatalis yang dapat mempercepat reaksi enzimatis, semakin banyak enzim yang terlibat dalam reaksi, semakin cepat reaksi yang terjadi (Singh et al., 2014). Laju reaksi katalitik enzim akan terus meningkat sampai mencapai titik jenuh, sehingga aktivitasnya akan turun bersamaan dengan tingkat kejenuhan enzim terhadap substrat. Hasil menunjukkan bahwa semakin tinggi dosis lakase akan meningkatkan nilai derajat cerah dan menurunkan nilai ERIC. Peningkatan derajat cerah dan penurunan nilai ERIC dari penelitian ini dapat dibandingkan dengan penelitian lain seperti disajikan pada Tabel 6.

Penggunaan lakase dapat meningkatkan derajat cerah pada saat suhu biodeinking dinaikkan pada rentang penelitian ini (Gambar 1). Suhu dapat menginduksi secara fisik pelonggaran mikrofibril-mikrofibril yang menyusun serat kertas atau bahan baku kertas. Sehingga memperluas kontak substrat dengan enzim. Namun, suhu yang terlalu tinggi dapat mendenaturasi enzim, sehingga dapat menurunkan aktivitas katalitiknya (Shuler and Kargi, 2002). Oleh karena itu, peningkatan suhu pada tingkat tertentu dapat membantu meningkatkan laju reaksi enzim, sehingga proses pelepasan tinta dari serat dapat berjalan lebih efektif. Sebaliknya, deinking pada suhu yang terlalu rendah menurunkan kemampuan katalitik enzim. Dengan demikian, biodeinking pada suhu yang terlalu rendah atau terlalu tinggi dapat menurunkan derajat cerah kertas (Lee, 2014).

\section{Kesimpulan}

Perlakuan biodeinking dengan enzim ekstrak kasar lakase yang divariasikan berdasarkan dosis, waktu, dan suhu dapat memberikan pengaruh terhadap peningkatan derajat cerah dan penurunan ERIC. Variasi dosis enzim (U/L), waktu (menit), dan suhu $\left({ }^{\circ} \mathrm{C}\right)$ dalam perlakuan dapat mempengaruhi perbedaan nilai derajat cerah dan ERIC yang signifikan. Persentase peningkatan derajat cerah kertas sekunder mencapai 15,22\% $(54,27 \%$ ISO $)$ sampai $25,03 \%(58,89 \%$ ISO $)$ dan penurunan ERIC mencapai 46,12\% (452,10 ppm) sampai $68,26 \%(266,4 \mathrm{ppm})$.

\section{Ucapan Terima Kasih}

Terima kasih kepada Lembaga Pengelola Dana Pendidikan (LPDP) yang telah mendukung pendanaan penelitian.

\section{Daftar Pustaka}

Akbarpour, I., Ghaffar, M. and Ghasemian, A. (2017) 'Deinking of Different Furnishes of Recycled MOW, ONP, and OMG Pulps in Silicate-Free Conditions Using Organic Complex of PHASS', BioResources, 8(1), pp. 31-44.

Baltierra-Trejo, E., Márquez-Benavides, L. and Sánchez-Yáñez, J.M.(2015) 'Inconsistencies and ambiguities in calculating enzyme activity: The case of laccase', Journal of Microbiological Methods. Elsevier, 119, pp. 126-131. doi: 10.1016/j.mimet.2015.10.007. 
Gupta, V., Garg, S., Capalash, N., Gupta, N. and Sharma, P. (2015) 'Production of thermoalkali-stable laccase and xylanase by coculturing of Bacillus sp. and B. halodurans for biobleaching of kraft pulp and deinking of waste paper', Bioprocess and Biosystems Engineering. Springer Verlag, 38(5), pp. $947-$ 956. doi: 10.1007/s00449-014-1340-0.

Hanung, C. D., Osmond, R., Risdianto, H., Suhardi, S. H. and Setiadi, T. (2013) 'Optimisasi produksi enzim lakase pada fermentasi kultur padat menggunakan jamur pelapuk putih Marasmius sp.: Pengaruh ukuran partikel, kelembapan, dan konsentrasi Cu', JURNAL SELULOSA, 3(02), pp. 67-74. doi: 10.25269/ jsel.v3i02.45.

Hong, R., Su, L., Chen, S., Long, Z. and Wu, J. (2017) 'Comparison of cutinases in enzymic deinking of old newsprint', Cellulose. Springer Netherlands, 24(11), pp. 5089-5099. doi: 10.1007/s10570-017-1424-5.

ISRI (2019) Recycling Industry Year Book 2019.

Leduc, C., Lanteigne-Roch, L.-M. and Daneault, C. (2011) 'Use of enzymes in deinked pulp bleaching', Cellulose Chemistry and Technology, 45(9-10), pp. 657-663.

Lee, D. T. (2014) Mechanism and novel deinking methodsfornon-impactprinted paper. Georgia Institute of Technology. Available at: https:// smartech.gatech.edu/handle/1853/53470.

Perdani, M. S., Margaretha, G., Sahlan, M. and Hermansyah, H. (2020) 'Solid state fermentation method for production of laccase enzyme with bagasse, cornstalk and rice husk as substrates for adrenaline biosensor', Energy Reports. Elsevier, 6, pp. 336-340. doi: 10.1016/J.EGYR.2019.08.065.

Permana, D. (2016) Purifikasi dan Karakterisasi Enzim Lakase dari Marasmiellus palmivorus. Institut Teknologi Bandung.

Risdianto, H., Sofianti, E., Suhardi, S. H. and Setiadi, T. (2012) 'Optimisation of laccase production using white rot fungi and agriculture wastes in solid state fermentation', ITB Journal of Engineering Science, 44 $\mathrm{B}(2)$, pp. 93-105. doi: 10.5614/itbj.eng. sci.2012.44.2.1.

Risdianto, H. and Sugesty, S. (2020) 'Kinetic Study on Crude Laccase of Marasmius sp. from Solid State Fermentation', Key Engineering Materials. Trans Tech Publications Ltd, 840, pp. 131-136. doi: 10.4028/WWW. SCIENTIFIC.NET/KEM.840.131.
Rumintang, S. A. (2016) Enzyme Enhanced Oil Recovery (EEOR) Menggunakan Lakase dari Marasmiellus palmivorus (Sharples) Desjardin (comb prov.). Institut Teknologi Bandung.

Saxena, A. and Singh Chauhan, P. (2017) 'Role of various enzymes for deinking paper: a review', Critical Reviews in Biotechnology, 37(5), pp. 598-612. doi: 10.1080/07388551.2016.1207594.

Sayyed, R. Z., Bhamare, H. M., Sapna, Marraiki, N., Elgorban, A. M., Syed, A., El-Enshasy, H. A. and Dailin, D. J. (2020) 'Tree bark scrape fungus: A potential source of laccase for application in bioremediation of non-textile dyes', PLOS ONE. Public Library of Science, 15(6), p. e0229968. doi: 10.1371/JOURNAL. PONE.0229968.

Shankar, S., Shikha, Bhan, C., Chandra, R. and Tyagi, S. (2018) 'Laccase based de-inking of mixed office waste and evaluation of its impact on physico-optical properties of recycled fiber', Environmental Sustainability. Springer Science and Business Media LLC, 1(3), pp. 233-244. doi: 10.1007/s42398-018-0021-3.

Shuler, M. L. and Kargi, F. (2002) Bioprocess Engineering: Basic Concepts. 2nd Editio. Prentice Hall International.

Singh, G., Kaur, K., Puri, S. and Sharma, P. (2014) 'Critical factors affecting laccase-mediated biobleaching of pulp in paper industry', Applied Microbiology and Biotechnology 2014 99:1. Springer, 99(1), pp. 155-164. doi: 10.1007/S00253-014-6219-0.

Singh, G., Arya, S. K., Gupta, V. and Sharma, P. (2017) 'Enzyme Technology for Lignocellulosic Biomass Conversion and Recycling to Valuable Paper and other Products: Challenges Ahead', Journal of Molecular Biology and Techniques, 2(1), pp. $1-6$.

Vicente, A. A. and Teixeira, J. A. (1995) 'Hydrodynamic performance of a three-phase airlift bioreactor with an enlarged degassing zone', Bioprocess Engineering 1995 14:1. Springer, 14(1), pp. 17-22. doi: 10.1007/ BF00369848.

Virk, A. P., Puri, M., Gupta, V., Capalash, N. and Sharma, P. (2013) 'Combined enzymatic and physical deinking methodology for efficient eco-friendly recycling of old newsprint', PloS one. PLoS One, 8(8), pp. 1-8. doi: 10.1371/ JOURNAL.PONE.0072346. 
Viswanath, B., Rajesh, B., Janardhan, A., Kumar, A. P. and Narasimha, G. (2014) 'Fungal Laccases and Their Applications in Bioremediation', Enzyme Research. Hindawi Limited, 2014, pp. 1-21. doi: 10.1155/2014/163242.

Xu, Q., Fu, Y., Gao, Y. and Qin, M. (2009) 'Performance and efficiency of old newspaper deinking by combining cellulase/ hemicellulase with laccase-violuric acid system', Waste Management, 29, pp. 14861490 .
Xu, Q. H., Wang, Y. P., Qin, M. H., Fu, Y. J., Li, Z. Q., Zhang, F. S. and Li, J. H. (2011) 'Fiber surface characterization of old newsprint pulp deinked by combining hemicellulase with laccase-mediator system', Bioresource Technology. Elsevier, 102(11), pp. 6536-6540. doi: 10.1016/J. BIORTECH.2011.03.051. 